\title{
Evaluation of water quality and human risk assessment due to heavy metals in groundwater around Muledane area of Vhembe District, Limpopo Province, South Africa
}

Joshua Nosa Edokpayi, Abimbola Motunrayo Enitan", Ntwanano Mutileni and John Ogony Odiyo

\begin{abstract}
Groundwater is considered as good alternative to potable water because of its low turbidity and perceived low contamination. The study assessed the physio-chemical and heavy metals concentrations in eight randomly selected boreholes water at Muledane village in Limpopo Province of South Africa and the results were compared with South African National standard permissible limit. The impacts of heavy metals on human health was further determined by performing quantitative risk assessment through ingestion and dermal adsorption of heavy metals separately for adults and children in order to estimate the magnitude of heavy metals in the borehole samples. Parameters such as turbidity, nitrate, iron, manganese and chromium in some investigated boreholes did not comply with standard limits sets for domestic water use. Multivariate analyses using principal component analysis and hierarchical cluster analysis revealed natural and anthropogenic activities as sources of heavy metal contamination in the borehole water samples. The calculated non-carcinogenic effects using hazard quotient toxicity potential, cumulative hazard index and chronic daily intake of groundwater through ingestion and dermal adsorption pathways were less than a unity, which showed that consumption of the water could pose little or no significant health risk. However, maximum estimated values for an individual exceeded the risk limit of $10^{-6}$ and $10^{-4}$ with the highest estimated carcinogenic exposure risk ( $\mathrm{CR}_{\text {ing }}$ ) for $\mathrm{Cr}$ and $\mathrm{Pb}$ in the groundwater. This could pose potential health risk to both adults and children in the investigated area. Therefore, precaution needs to be taken to avoid potential $\mathrm{CR}_{\text {ing }}$ of people in Muledane area especially, children using the borehole water.
\end{abstract}

Keywords: Contamination, Groundwater, Health risk, Multivariate analysis, South Africa

\section{Introduction}

Sustainable access to potable water have been achieved in different developed countries of the world, but this is not true for many developing countries. In Africa, access to potable water has been achieved in a few cities but not in the entire region. This problem is more pronounced in rural areas, some of which does not have water supply

\footnotetext{
*Correspondence: enitanabimbola@gmail.com Department of Hydrology and Water Resources, University of Venda, Private Bag X5050, Thohoyandou 0950, South Africa
}

infrastructure [1]. Residents of such rural communities often resort to different sources of water. The most commonly used sources include: Rivers, streams, boreholes, lakes, etc. Most of these various alternative sources are susceptible to water pollution. Some of the major sources of pollution include the discharge of domestic, industrial and agricultural wastewater into freshwater bodies.

Groundwater is often considered as the best of these alternatives, owing to natural protection from pollution when compared to surface and perceived natural filtration as water flows down during rainy period. 
Groundwater as one of the natural resources is of fundamental importance to human life, because of its perceived good microbiological quality in the natural state and as a result, it is often the preferred source of drinking water supply as treatment is limited to disinfection. Aesthetically, it looks clean and acceptable to various people as it is often free from odour and sometimes do have a pleasant taste. Despite the perceived safety associated with groundwater consumption, several researches have shown that groundwater can also be susceptible to contamination [2-4]. Some factors that influence the quality of groundwater include the geology of the aquifer, climate and anthropogenic activities [5-8].

The use of groundwater sources has increased rapidly in many countries of the world due to population growth, increased industrialization and scarcity of water related to climate change. Although surface water has been extensively used in various water infrastructure, increased utilization coupled with other aforementioned factors has led to an increase in the use of groundwater sources. Groundwater are often used for drinking, irrigation and several industrial processes. The global use of groundwater is often underestimated and climatic factor has also been extensively debated to influence the available water volume in the aquifer [9]. Several countries of the world are experiencing acute water scarcity, but this problem is exacerbated in arid and semi-arid countries of the world. The use of shallow, such as hand dug wells and deep groundwater sources (boreholes) are common in South Africa. Most of the communities that depends on groundwater sources do not know the quality of water they drink as they often presume that groundwater has a good water quality. Groundwater can be contaminated by the ingress of human and animal waste into the aquifer [10]. This could be through the grazing of animals, discharge of domestic and industrial wastewater, use of pesticides and fertilizers in agriculture [11].

In some part of South Africa, groundwater is a key component of the water resources, and one of the sources of water supply. Report have shown that about two-thirds of South African population depend on groundwater for drinking $[12,13]$ with about $65 \%$ of the total supply in the rural areas [14]. As such, it provides some basic water requirement, since the country's surface water resources are unevenly distributed and cannot meet the growing demand for water [15]. In rural areas, boreholes are located either close to a pit toilet or downstream of soak away pits or adjoining landfills or dumpsites [16]. Some groundwater is poorly managed due to its invisible nature and it usually takes a long time to notice when it has become polluted and once it is contaminated, its quality cannot be restored by just stopping the pollutants from source, because contamination may continue after the source has been stopped or removed [17, 18]. In the rural and peri-urban areas, most of the groundwater supplies are usually untreated and it has been reported that it is difficult for groundwater to purify itself, often impossible and very expensive to treat, thereafter [14]. The use of groundwater sources of unknown quality puts the consumers at risk to possible waterborne diseases. Bessong et al. [19] reported high levels of fecal contamination in groundwater sources around Tshikuwi Community in Vhembe District of South Africa. High fluoride levels have been reported by Odiyo and Makungo [20] in groundwater sources around Siloam village. Arsenic contamination of groundwater sources has been reported in the world [2, 21].

Thohoyandou, Vhembe District of Limpopo, South Africa is experiencing a rapid population growth and this has led to an increase in the generation of waste. Muledane village in Thohoyandou consist of households that rely on groundwater while, some areas are reserved for municipal landfill site, farming, wastewater treatment plant and cemeteries. Landfills have been identified as one of the major threats to groundwater resources in this area [22]. There is currently no published data on the status of groundwater quality in Muledane village and possible health risks that these water sources may have on humans, unlike other reports of groundwater quality in South Africa that reported the impact of heavy metals, physical and chemical properties on human health [23, 24]. Hence, there is an urgent need to assess water quality of groundwater in Muledane village because contaminated water by faeces, leachate and other non-point sources could have economic and social development implications and human health risks due to activities around this area. It is assumed that water quality impairment might be severe in Muledane village of Thohoyandou. To this end, the aim of this study was to assess the status of water quality from boreholes situated at Muledane area near Thohoyandou by quantifying heavy metal concentration and determine possible health risk due to exposure of human to heavy metals.

\section{Materials and methods}

\section{Study area and land use}

The study area is located at Thohoyandou block $J$ in Thulamela Municipality Government area of Vhembe District, Limpopo province. Geological coordinates of Muledane area is located approximately on longitudes $30^{\circ} 1^{\prime} 0^{\prime \prime} \mathrm{E}$ and latitudes $23^{\circ} 29^{\prime} 0^{\prime \prime} \mathrm{N}$, respectively at $734 \mathrm{~m}$ elevation above the sea level. The Thulamela municipality area is approximately $2966,4 \mathrm{~km}$ in extent which covers $13,86 \%$ of the total area of the Vhembe District with an estimated population of 537,454 [25]. Activities around Muledane area consist of schools, churches, agricultural 
activities, residential and hotels. It also encompasses dense bushes and trees, sewage treatment plant and the municipal landfill site which make up a large portion of the study area. Thohoyandou falls under the summer climatic conditions of South Africa with very warm conditions and the annual rainfall ranging from 400 to $800 \mathrm{~mm}$. Rainfall during summer is very high with little rainfall in winter. The temperatures may reach up to 37 and $23{ }^{\circ} \mathrm{C}$ on the average in summer and winter, respectively [26]. The 1:1,000,000 scale geological map of South Africa from the council for Geoscience shows that Muledane is dominated by fractured aquifers [27]. The depth of water table derived from National Groundwater Database (NGDB) range from 15 to $30 \mathrm{~m}$. The recharge map compiled by DWAF as part of the Groundwater Resources Assessment study of 2004 indicate that Muledane range from 10 to $50 \mathrm{~mm} /$ annum [28].

\section{Sample collection, preparation and storage}

Groundwater samples were collected as outlined by Fitfield and Haines [29]. Briefly, plastic bottles were washed and stored in 10\% nitric acid for 2 days and rinsed with double distilled water before sampling. A total of 24 groundwater samples were collected from eight randomly selected boreholes at Muledane area of Thohoyandou. Borehole samples were label according to their sources using the code B1-B8. The bottles were rinsed three times and taps were allowed to run for at least 5 min before collection of samples and labelled accordingly. Samples for metals were preserved by adding $3 \mathrm{~mL}$ of concentrated $\mathrm{HNO}_{3}$. All the samples were placed on an ice chest and transported to the University of Venda then preserved at $-4{ }^{\circ} \mathrm{C}$ in the refrigerator for further analysis.

\section{Analytical methods}

Onsite analysis of the physico-chemical parameters such as electrical conductivity (EC) and turbidity were measured on-site using Cyberscan 500 conductivity meter (AQ2010 LABOTEC) and turbidity meter, respectively. The $\mathrm{pH}$ and temperature were measured using $\mathrm{pH}$ meter (H1 8014 HANNA instrument). Appropriate portion of the collected groundwater samples were digested with concentrated $\mathrm{HNO}_{3}$ for heavy metals analysis according to the method of Sharma [30] and analysed using an inductively coupled plasma optical atomic spectrophotometer (ICP-OES) (ThermoScientific). The instrument was standardized with seven working standard solutions (multi-point linear fitting) for Copper $(\mathrm{Cu})$, Manganese $(\mathrm{Mn})$, Iron $(\mathrm{Fe})$, Chromium $(\mathrm{Cr})$, Cadmium $(\mathrm{Cd})$, Zinc $(\mathrm{Zn})$ and Lead $(\mathrm{Pb})$ and analytical precession was checked by frequently analysing the standards as well as blanks. An Ion Chromatography (Methrohm 850 Professional
IC) was used to analyze the anions concentration including nitrates, chlorine, fluorine, and sulphates in water samples collected from different boreholes so as to check the groundwater's suitability for domestic use. The IC has $20 \mu \mathrm{L}$ injection loop, Ionpac AG144×50 mm guard and AS144× $250 \mathrm{~mm}$ analytical columns with conductivity detector. Multiple working solutions of 1, 5, 10 and 20 units/ppm were prepared and used in calibrating each anion Fluoride $\left(\mathrm{F}^{-}\right)$, Chloride $\left(\mathrm{Cl}^{-}\right)$, Nitrate $\left(\mathrm{NO}_{3}{ }^{-}\right)$and Sulphate $\left(\mathrm{SO}_{4}{ }^{2-}\right)$. An eluent $1.0 \mathrm{Mm} \mathrm{NaHCO}{ }_{3} / 3.5 \mathrm{Mm}$ $\mathrm{Na}_{2} \mathrm{CO}_{3}$ was prepared and pumped through the IC system. The standards were injected into the instrument sequentially, in order to perform calibration for each element. The samples were filtered through a $0.45 \mu \mathrm{m}$ Millipore filter and then injected into IC machine for analysis.

\section{Quantitative health risk assessment}

Human exposure risk pathways of an individual to trace metals contamination could be through three main pathways including inhalation via nose and mouth, direct ingestion and dermal absorption through skin exposure. Common exposure pathways to water are dermal absorption and ingestion routes. Exposure dose for determining human health risk through these two pathways have been described in the literature [31-33] and can be calculated using Eqs. 1 and 2 as adapted from the US EPA risk assessment guidance for superfund (RAGS) methodology $[31,33]$.

$$
\begin{gathered}
\operatorname{Exp}_{\text {ing }}=\frac{C_{\text {water }} \times I R \times E F \times E D}{B W \times A T} \\
\operatorname{Exp}_{\text {derm }}=\frac{\left(C_{\text {water }} \times S A \times K P \times E T \times E F \times E D \times C F\right)}{(B W \times A T)}
\end{gathered}
$$

where, $\operatorname{Exp}_{\text {ing }}$ : exposure dose through ingestion of water $\left(\mathrm{mg} / \mathrm{kg} /\right.$ day); $\operatorname{Exp}_{\text {derm }}$ : exposure dose through dermal absorption $\left(\mathrm{mg} / \mathrm{kg} /\right.$ day); $\mathrm{C}_{\text {water }}$ : average concentration of the estimated metals in water $(\mu \mathrm{g} / \mathrm{L})$; IR: ingestion rate in this study (2.2 L/day for adults; $1.8 \mathrm{~L} /$ day for children); EF: exposure frequency (365 days/year); ED: exposure duration (70 years for adults; and 6 years for children); BW: average body weight (70 kg for adults; $15 \mathrm{~kg}$ for children); AT: averaging time (365 days/year $\times 70$ years for an adult; 365 days/year $\times 6$ years for a child); SA: exposed skin area $\left(18,000 \mathrm{~cm}^{2}\right.$ for adults; $6600 \mathrm{~cm}^{2}$ for children); Kp: dermal permeability coefficient in water, $(\mathrm{cm} / \mathrm{h})$, 0.001 for $\mathrm{Cu}, \mathrm{Mn}, \mathrm{Fe}$ and $\mathrm{Cd}$, while 0.0006 for $\mathrm{Zn} ; 0.002$ for $\mathrm{Cr}$ and 0.004 for $\mathrm{Pb}$ [34]; ET: exposure time $(0.58 \mathrm{~h} /$ day for adults; $1 \mathrm{~h} /$ day for children) and CF: unit conversion factor $\left(0.001 \mathrm{~L} / \mathrm{cm}^{3}\right)[31-33,35]$.

Potential non-carcinogenic risks due to exposure of heavy metals were determined by comparing the 
calculated contaminant exposures from each exposure route (ingestion and dermal) with the reference dose (RfD) [31] using Eq. 3 in order to develop hazard quotient (HQ) toxicity potential of an average daily intake to reference dose for an individual via the two pathways using Eq. 4.

$$
H Q_{i n g / d e r m}=\frac{E_{x p} p_{i n g} / \text { derm }}{R f D_{\text {ing } / \text { derm }}}
$$

where $\mathrm{RfD}_{\text {ing/derm }}$ is ingestion/dermal toxicity reference dose $\left(\mathrm{mg} / \mathrm{kg} /\right.$ day). The $\mathrm{RfD}_{\text {ing }}$ and $\mathrm{RfD}_{\text {derm }}$ values were obtained from the literature [31-33, 35, 36]. An HQ under 1 is assumed to be safe and taken as significant non-carcinogenic [37], but HQ value above 1 may be a major potential health concern in association with overexposure of humans to the contaminants.

To assess the overall potential non-carcinogenic effects posed by more than one metal and pathway, the sum of the computed HQs across metals was expressed as hazard index (HI) using Eq. 4 [31]. HI > 1 showed that exposure to the groundwater could have a potential adverse effect on human health [32, 34].

$$
H I=\sum_{i=1}^{n} H Q_{i n g} / d e r m
$$

where $\mathrm{HI}_{\text {ing/derm }}$ is hazard index via ingestion or dermal contact. Chronic daily intake (CDI) of heavy metals through ingestion was calculated using Eq. 5;

$$
C D I=C_{\text {water }} \times \frac{D I}{B W}
$$

where $C_{\text {water }}$, DI and BW represent the concentration of trace metal in water in $(\mathrm{mg} / \mathrm{kg})$, average daily intake of water $(2.2 \mathrm{~L} /$ day for adults; $1.8 \mathrm{~L} /$ day for children) and body weight (70 kg for adults; $15 \mathrm{~kg}$ for children), respectively. Carcinogenic risk (CR) through ingestion pathway was estimated using Eq. 6:

$$
C R_{\text {ing }}=\frac{\text { Exp }_{\text {ing }}}{S F_{\text {ing }}}
$$

where, $\mathrm{CR}_{\text {ing }}$ is the carcinogenic risk via ingestion route and $\mathrm{SF}_{\text {ing }}$ is the carcinogenic slope factor where $\mathrm{Pb}$ is $8.5 \mathrm{E}, \mathrm{Cd}$ is $6.1 \mathrm{E}+03$ and $\mathrm{Cr}$ is $5.0 \mathrm{E}+02 \mu \mathrm{g} / \mathrm{kg} /$ day $[33,34$, $36]$. The $\mathrm{CR}_{\text {ing }}$ values for other metals were not calculated due to unavailability of the $\mathrm{SF}_{\text {ing }}$ values.

\section{Statistical analysis}

GraphPad Prism version 5.0 for Windows (GraphPad Software, San Diego California, USA) was used for both statistical analysis at 95\% confidence limit and the graphs. Mean values of the parameters obtained for the various locations were compared to DWAF [38] and WHO [39] guidelines for domestic water use. Multivariate statistics in terms of principal component analysis (PCA)/factorial analysis (FA) and hierarchical agglomerative analysis (HAC) were performed using Xlstart statistical software [40]. The PCA is used to established major variation and relationships among the different metals. Pearson correlation was calculated for different metals in groundwater samples and significant principal components (PC) was selected based on the varimax orthogonal rotation with Kaiser normalization at eigenvalues greater than one. The HCA was used to identify groups that shows similar characteristics or variables and dendrogram to provide a visual summary of the results based on dimensionality of the original data [34].

\section{Results and discussion}

Table 1 shows the turbidity, temperature, $\mathrm{pH}$, conductivity and TDS of groundwater samples collected from Muledane village. The $\mathrm{pH}$ varied from slightly acidic to neutral (6.04-7.41) throughout the sampling period. These values were within the recommended guideline of DWAF (6.0-9.0) for domestic water use [38]. The $\mathrm{pH}$ values for all borehole except for B2 was higher in the months of January as compared to other months. This is not expected because the $\mathrm{pH}$ of rainwater is low and could influence groundwater's $\mathrm{pH}$ due to high infiltration of aquifer during heavy rainfall. The acidity or alkalinity of water can affect plant growth, benthic organisms, soil and crops when used for irrigation. This could also indicate possible corrosion problems and potential heavy metals contamination. Copper, $\mathrm{Zn}$ and $\mathrm{Cd}$ are associated with low values of $\mathrm{pH}$, e.g., a $\mathrm{pH}$ of 2 will cause water to be acidic and unsuitable for human consumption [41].

The EC average level for each sampling point during the monitoring period were $63.2,42.5,23.92,17.56$, $15.69,10.52,17.71$ and $51.1 \mathrm{mS} / \mathrm{cm}$ for samples B1-B8, respectively. The mean values recorded for conductivity were within the recommended guideline of $<70 \mathrm{mS} / \mathrm{cm}$ for domestic water use [38]. However, measured values for B1 throughout the investigation were very close to the recommended guideline value of DWAF (Table 1). Hence, frequent monitoring of hotels such as the investigated B1 borehole is required, because this parameter might accumulate overtime and exceeds the recommended level. EC plays an important role in water quality as it gives an indication of salinity and TDS present in water [41]. The total dissolved solids (TDS) that measures the dissolution mechanism of organic and inorganic materials in groundwater were low and below the WHO value of $1000 \mathrm{mg} / \mathrm{L}$. Turbidity recorded (0.33-14.9 NTU) were within the acceptable limit set by DWAF $(<1$ NTU) and WHO (< $5 \mathrm{NTU})$ for domestic water except in April 
where B3, B4, B5, B6, and B7 exceeded the DWAF limit but fell within the guideline value of WHO for domestic water (Table 1), while B3 (14.9 NTU) and B5 (5.76 NTU) samples during April exceeded both standard limits. Turbidity is caused by colloidal or suspended particles that may originate from organic or inorganic matter or combination of both in water, thus prevents transmission of light through the water. Its affect the appearance and the aesthetic property of water which shows that there is a slight risk of potential secondary health effects turbidity between 1 and $20 \mathrm{NTU}$ and minor risk if used for food preparation [41].

\section{Anions}

Table 2 shows the mean concentration of $\mathrm{F}, \mathrm{Cl}, \mathrm{NO}_{3}$ and $\mathrm{SO}_{4}$ in groundwater samples obtained around Muledane village in January, April and June. Fluoride and chloride concentrations ranged from 0.007 to $0.167 \mathrm{mg} / \mathrm{L}$ and 4.3 to $46.9 \mathrm{mg} / \mathrm{L}$, respectively. All the boreholes complied with the limit values set by DWAF [38] and WHO [39]. A small concentration of fluoride in the ppb level is needed for good dental health [41]. The highest and lowest concentration of nitrate obtained during the study period was in January and April for B8 and B4 samples with the concentration of 125.18 and $0.6 \mathrm{mg} / \mathrm{L}$ (Table 2), respectively. The recommended water quality guideline for nitrate is $<22$ and $<50 \mathrm{mg} / \mathrm{L}$ by DWAF [38] and WHO [39], respectively. The mean concentration of $\mathrm{NO}_{3}{ }^{-}$for all the boreholes during investigation failed to comply with the recommended guideline except for B4 (Table 2). The water samples from the hotel (B1) had higher concentration of nitrate 121.64, 53.129 and $51.55 \mathrm{mg} / \mathrm{L}$ in January, April and June, respectively compared to other boreholes. According to DWAF [38], more than $10 \mathrm{mg} / \mathrm{L}$ of nitrate may cause methaemoglobinaemia in infants and may also result in the occurrence of mucous membrane irritation in adults if it is more than $20 \mathrm{mg} / \mathrm{L}$.

\section{Heavy metal concentration in borehole water Chromium}

Figure $1 \mathrm{a}-\mathrm{c}$ shows the concentration of $\mathrm{Fe}, \mathrm{Cd}, \mathrm{Cr}, \mathrm{Zn}$, $\mathrm{Mn}, \mathrm{Cu}$ and $\mathrm{Pb}$ in the water samples collected from the investigated boreholes at Muledane village during the study period. Chromium concentrations were in the range of $0.005-0.15 \mathrm{mg} / \mathrm{L}$ samples for B1-B8 throughout the study. The samples taken from boreholes B1 to B7 in January did not comply with the recommended water quality guidelines of $<0.05 \mathrm{mg} / \mathrm{L}$ for both WHO [39] and DWAF [38] for domestic use (Table 2). High $\mathrm{Cr}$ concentration in January for these samples could be as results of high infiltration of water and leachates from landfill and dumpsite due to heavy rainfall. Disposal of metal products around this area could have led to high concentration of $\mathrm{Cr}$ in the boreholes [42]. According to DWAF [38], consumption of water with $\mathrm{Cr}$ concentration greater than $0.05 \mathrm{mg} / \mathrm{L}$ has possible risk of inducting gastrointestinal cancer following long-term exposure, undesirable taste and slight nausea in humans. Furthermore, in vitro study has shown that high $\mathrm{Cr}$ (III) concentration in the cell could cause DNA damage in humans $[43,44]$. It is noteworthy to say that water samples taken from the hotel is very high in $\mathrm{NO}_{3}$ and $\mathrm{Cr}$, therefore proper treatment of the water is necessary to make it suitable for the public.

\section{Iron}

The mean concentrations of Fe obtained throughout the assessment ranged from 0.15 to $1.86 \mathrm{mg} / \mathrm{L}$ (Fig. 1a-c) and were beyond the recommended concentration of $<0.1$ and $0.3 \mathrm{mg} / \mathrm{L}$ set by DWAF [38] and WHO [45], respectively, for domestic water use. Elevated concentration was observed in January for B4 $(1.86 \mathrm{mg} / \mathrm{L}), \mathrm{B} 7$ $(0.72 \mathrm{mg} / \mathrm{L})$ as shown in Fig. 2a; in April B4 $(0.88 \mathrm{mg} / \mathrm{L})$, B5 $(0.96 \mathrm{mg} / \mathrm{L})$ (Fig. 1b), finally in June, B2 $(1.14 \mathrm{mg} / \mathrm{L})$ and B3 (1.45 mg/L, Fig. 1c) were measured. Water with Fe concentration of less than $0.3 \mathrm{mg} / \mathrm{L}$ have slight effects on taste and other marginal aesthetic effects such as slight staining of white clothes if used for laundry purposes. However, more than $0.3 \mathrm{mg} / \mathrm{L}$ was present in water samples taken from boreholes B4-B7 during the months of January and April. This could result in an adverse aesthetic and health effects when ingested by the residents around Muledane area [33]. High concentration of Fe in Muledane boreholes groundwater could be due to leaching of $\mathrm{Fe}$ from the sewer pipes and from other nonpoint sources such as storm runoff, disposal of metal and municipal landfill. This may also be as a result of nitrate leaching in groundwater, oxidation and decrease in $\mathrm{pH}$ could lead to dissolution of iron thus, increases the $\mathrm{Fe}$ concentration in groundwater $[33,46]$.

\section{Manganese}

The concentrations of Manganese varied from 0.01 to $1.22 \mathrm{mg} / \mathrm{L}$ for samples B1-B8 (Fig. 1a-c). All boreholes complied with the WHO [39] guideline concentration of $<0.4 \mathrm{mg} / \mathrm{L}$ for domestic water use except for borehole, B1 in January (Fig. 1a) and B4-B7 in April (Fig. 1b). However, all boreholes failed to comply with the standard limit of $<0.05 \mathrm{mg} / \mathrm{L}$ set by DWAF [38] for domestic water. This may be as a result of landfill leachates leaching to the boreholes, industrial effluent or indirect contact of water in the boreholes with the sewage. According to DWAF [41], no aesthetic effects associated with the use of water with less than $0.05 \mathrm{mg} / \mathrm{L} \mathrm{Mn}$ concentration, but concentration between 0.10 and $0.15 \mathrm{mg} / \mathrm{L}$ could cause critical stain and taste problems $[38,39]$. 


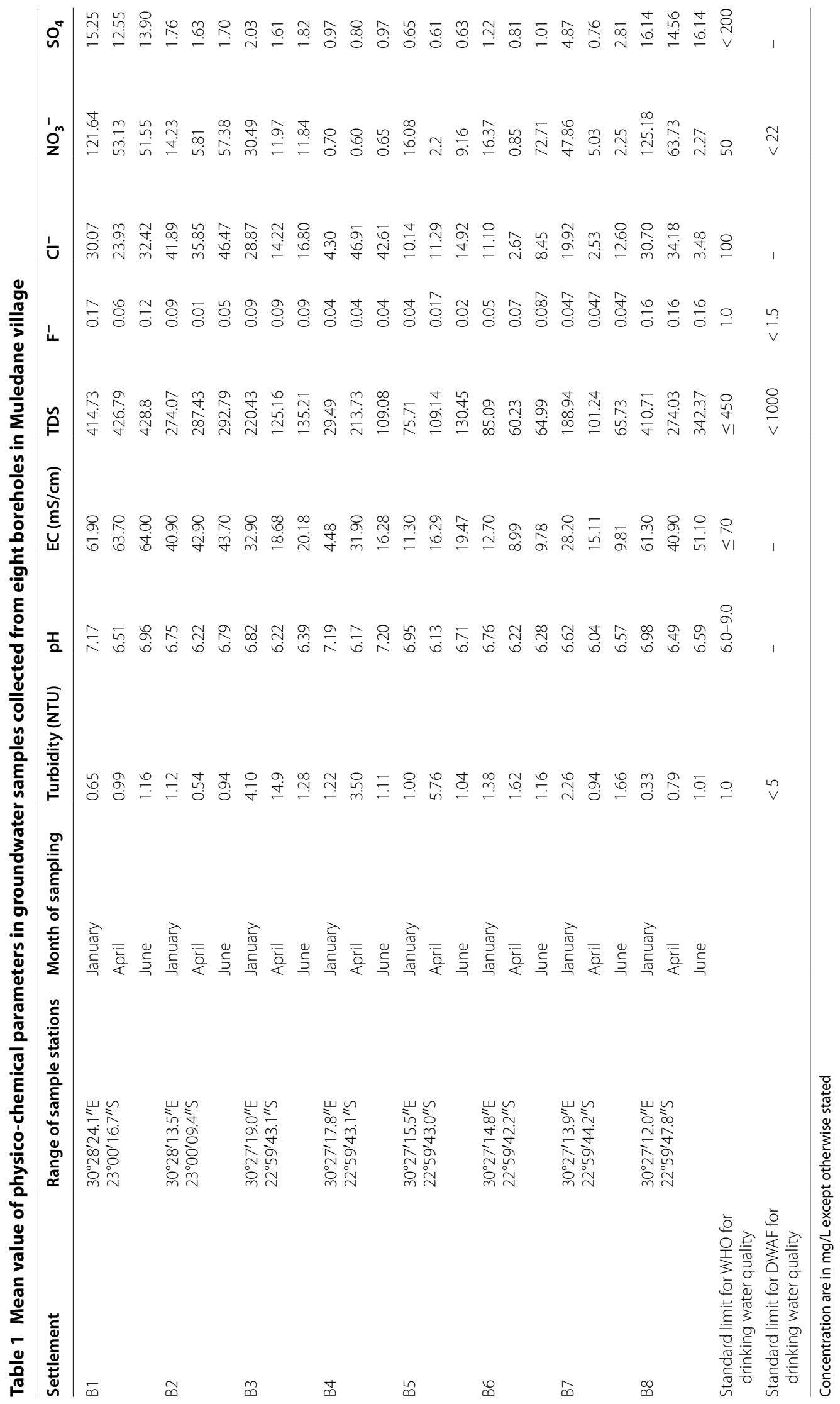




\section{Copper}

Average concentration of $\mathrm{Cu}$ in all the groundwater samples ranged between 0.01 and $0.41 \mathrm{mg} / \mathrm{L}$ (Fig. 1a-c). The concentration is below the standard limits of $<1.0$ and $<2 \mathrm{mg} / \mathrm{L}$ set by DWAF [38] and WHO [39], respectively for domestic purpose (Table 2). No adverse health effect associated with consumption of water with less than $1.0 \mathrm{mg} / \mathrm{L}$ concentration of $\mathrm{Cu}$ [41]. Higher concentration was measured at site B4 as compared to other groundwater samples in the month of April (Fig. 1b). The higher concentration could be as a result of $\mathrm{Cu}$ particles from the pipes into the borehole water.

\section{Lead}

The concentrations of $\mathrm{Pb}$ ranged between 0.002 and $0.026 \mathrm{mg} / \mathrm{L}$ and the mean concentrations in water samples throughout the study period for all the boreholes (B1-B8) are depicted in Fig. 1a-c. Although, the mean value obtained was below the standard guidelines of $0.01 \mathrm{mg} / \mathrm{L}$ set by both DWAF [38] and WHO [39] for domestic water use, except sample B6 that exceeded the limits. Specifically, the concentration of B2 $(0.026 \mathrm{mg} / \mathrm{L})$ and B3 $(0.023 \mathrm{mg} / \mathrm{L})$ in April during autumn and B6 $(0.023 \mathrm{mg} / \mathrm{L})$ in June during winter was high (Fig. 1c). Studies have shown that chronic $\mathrm{Pb}$ exposure can cause anaemia and high blood pressure especially in older and middle age groups. Exposure to high concentration could cause kidney and brain damage in male [47], while water with less than $0.05 \mathrm{mg} / \mathrm{L}$ concentration of $\mathrm{Pb}$ could have slight risk of behavioural changes and possibility of neurological impairment in foetuses and young children developing their brain tissues [38].

\section{Zinc and cadmium}

During the study period, all boreholes complied with the recommended standard limits of $<5.0$ and $<3.0 \mathrm{mg} / \mathrm{L}$ set for $\mathrm{Zn}$ by both WHO and DWAF, respectively for domestic purposes. The maximum and minimum detection values of 0.003 and $0.24 \mathrm{mg} / \mathrm{L}$ were recorded in April (B3 sample) and June (B5 sample) as shown in Fig. 1b and c, respectively. The concentration in the collected samples might be due to high water infiltration in April due to rain as compared to other months (Fig. 1). Hence, all boreholes water has little to no health effects because $\mathrm{Zn}$ is known to have antioxidant properties that protect humans against accelerated aging of muscles and skin. It's also helps in healing process after an injury if moderate and recommended dosage is ingested [33]. In addition, the concentration of $\mathrm{Cd}$ throughout the study period was below the standard limits set by DWAF [38] and WHO [39] which is 0.005 and $0.003 \mathrm{mg} / \mathrm{L}$, respectively for domestic water use.

\section{Multivariate analysis}

The PCA/FA loading factors for the selected metals in the borehole samples taken around Muledane village for January, April and June are shown in Table 3. Throughout the monitoring period, two important principal components (PCs) were significant with eigenvalues $>1$, explaining higher total variance of 59.35, 76.74 and $70.58 \%$ for January, April and June, respectively (Table 3 and Fig. 2). In January, two PCs were identified by PCA/ FA to be $35.57 \%$ (PC1) and $23.75 \%$ (PC2) (Fig. 2a). In April, PC1 and PC2 were 45.09 and $31.65 \%$ with eigenvalues $>2$ (Table 3 and Fig. 2b), while in June, PC1 and PC2 has variables of 44.76 and $22.82 \%$ (Fig. 2c), respectively.

Pearson correlation showed the inter-relationship between all metals (Table 4). Positive significant correlation of $\mathrm{Cu}$ with $\mathrm{Fe}\left(\mathrm{R}^{2}=0.734\right)$ and $\mathrm{Zn}\left(\mathrm{R}^{2}=0.779\right)$ were observed in January with weak positive correlation $\left(R^{2} \geq 0.3\right)$ between chromium-iron and cadmiumcopper. Copper was negatively correlated with $\mathrm{Mn}$ $\left(\mathrm{R}^{2}=-0.633\right)$ and $\mathrm{Pb}\left(\mathrm{R}^{2}=-0.444\right)$. In April, $\mathrm{Pb}$ was strongly and positively correlated with $\mathrm{Cr}\left(\mathrm{R}^{2}=0.971\right)$; Mn with Fe $\left(R^{2}=0.823\right)$ and $\mathrm{Cu}\left(\mathrm{R}^{2}=0.710\right)$, while strong negative correlation was observed between $\mathrm{Cd}$ and

Table 2 Guidelines for drinking water quality set by South Africa and World Health Organisation (WHO)

\begin{tabular}{lll}
\hline Heavy metal & $\begin{array}{l}\text { Standard limit for drinking water } \\
\text { quality in (mg/L) by DWAF [38] }\end{array}$ & $\begin{array}{l}\text { Health based guideline in } \\
\text { (mg/L) by WHO [39] }\end{array}$ \\
\hline Cadmium & $0-0.005^{\mathrm{a}}$ & 0.003 \\
Copper & $0-1$ & 2 \\
Chromium & $0-0.05^{\mathrm{a}, \mathrm{b}}$ & $<0.05$ \\
Iron & $0-0.1$ & $<0.3$ \\
Lead & $0-0.1$ & 0.01 \\
Manganese & $0-0.05$ & $<0.5$ \\
Zinc & $0-3$ & $<3$
\end{tabular}

DWAF Department of Water Affairs and Forestry, South Africa

a Tentative guidelines

b For chromium (VI) 


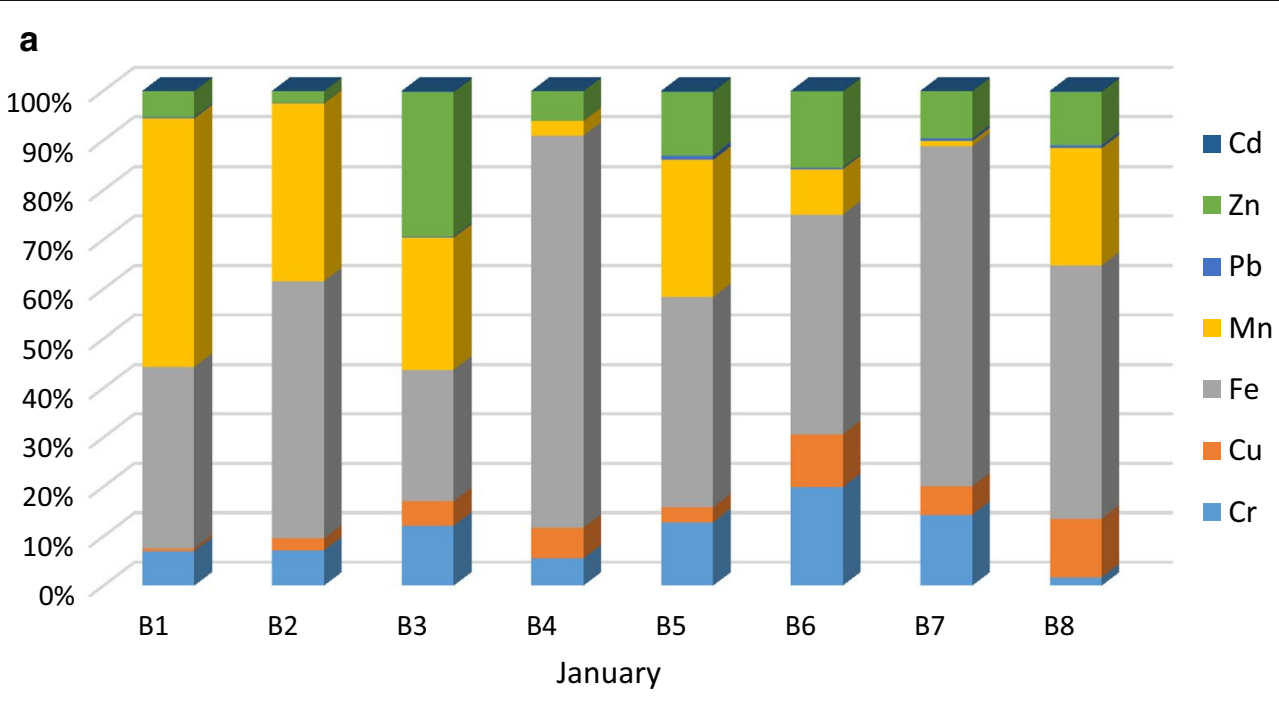

b

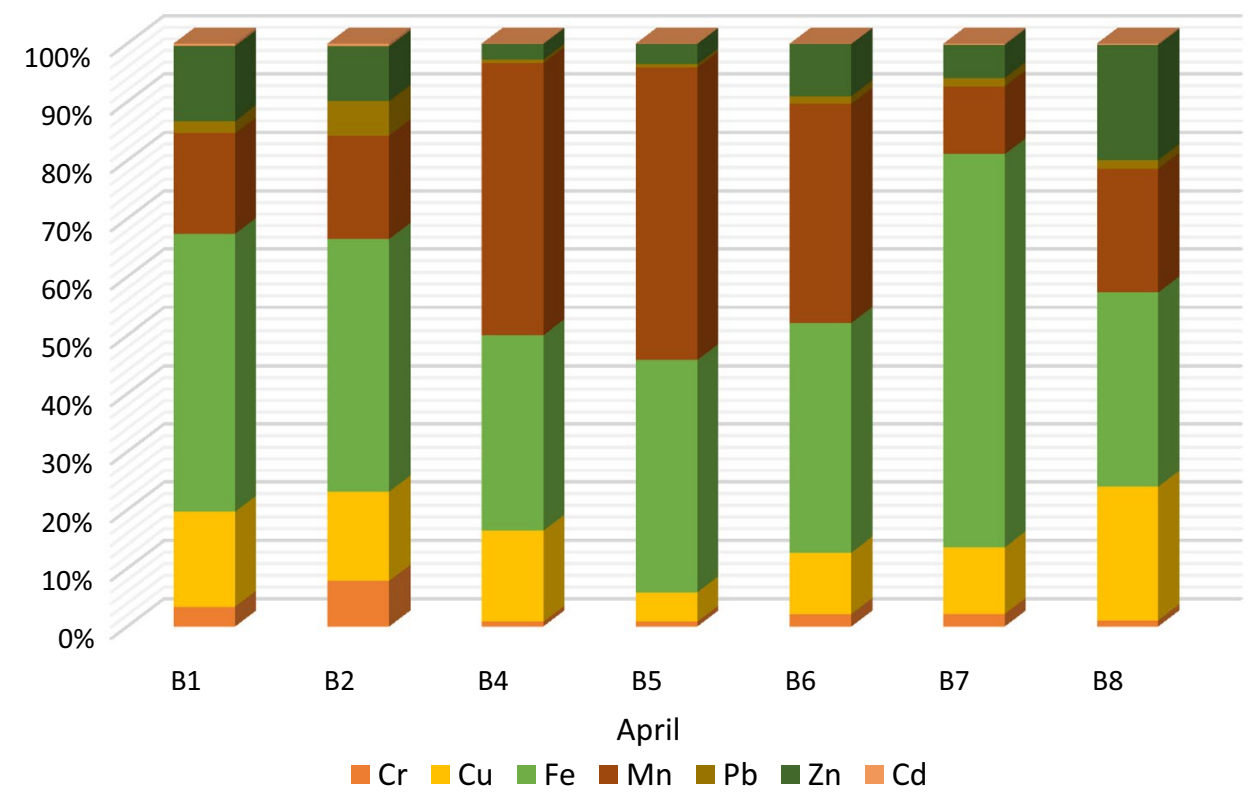

c

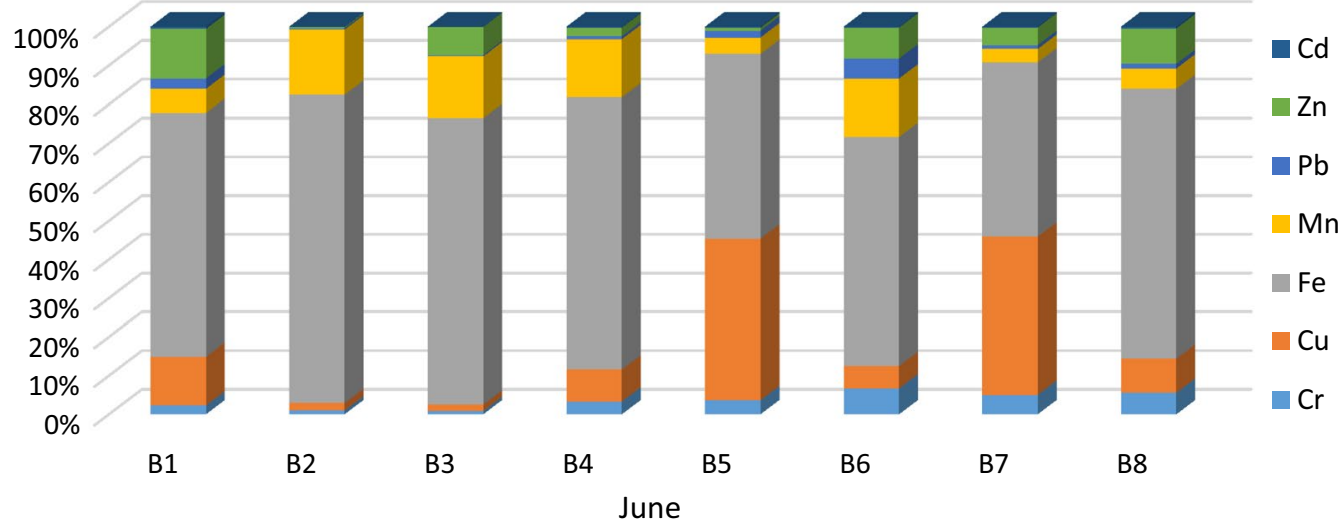

Fig. 1 Mean value of physico-chemical parameters in groundwater samples collected from eight boreholes in Muledane village 

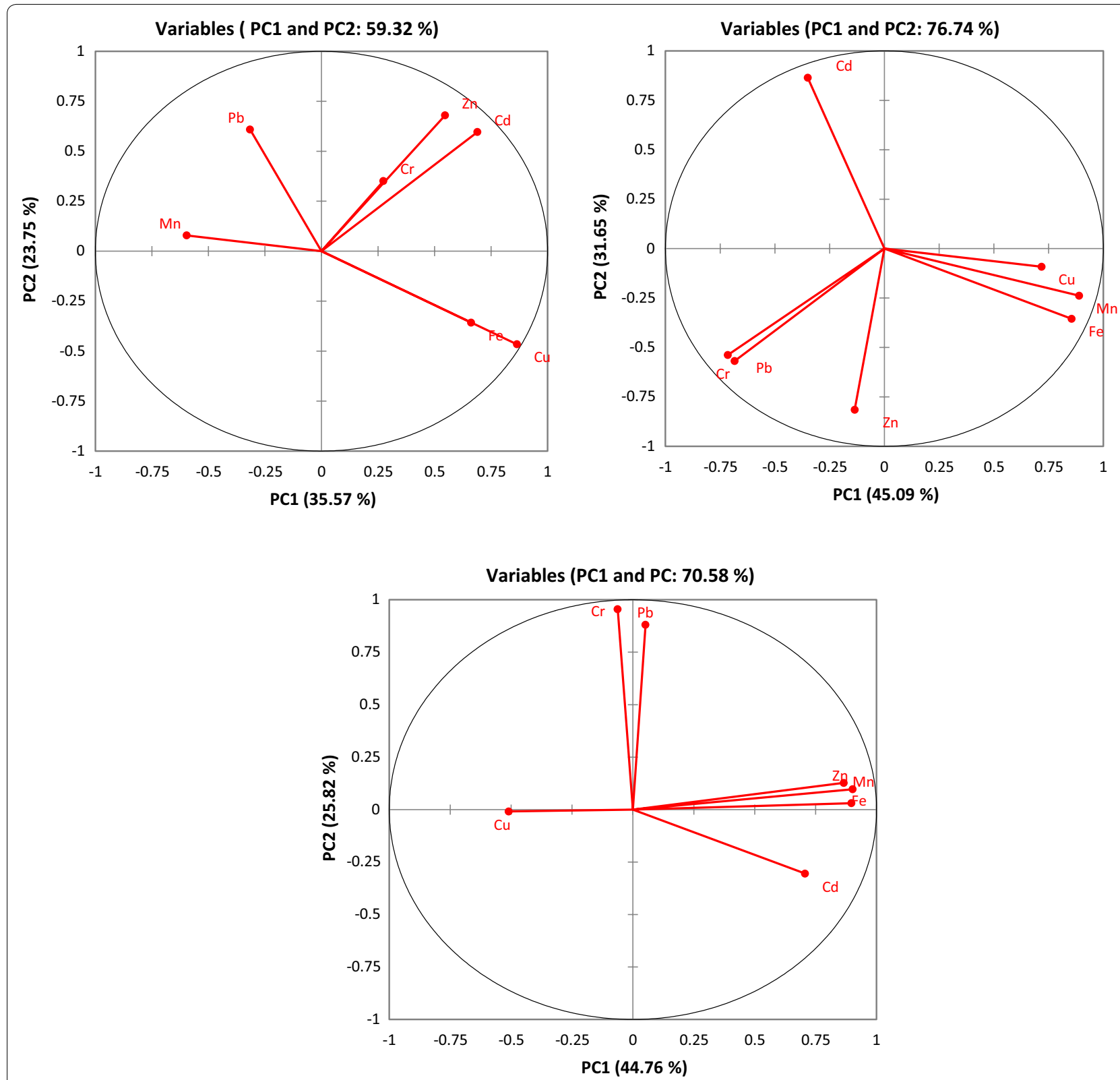

Fig. 2 The principal component analysis (PCA) biplots showing the relationships between heavy metals in the borehole samples around Muledane village of Limpopo, South Africa

Zn $\left(R^{2}=-0.712\right)$. In June, strong relationship among metals was also observed, Fe exhibited relationship with $\mathrm{Mn}$ and $\mathrm{Zn}\left(\mathrm{R}^{2}=0.995,0.662\right.$, respectively), $\mathrm{Pb}$ correlated with $\mathrm{Cr}\left(\mathrm{R}^{2}=0.717\right)$ while, $\mathrm{Zn}$ with $\mathrm{Mn}, \mathrm{Cd}$ and $\mathrm{Fe}$ $\left(R^{2}=0.662,0.738\right.$ and 0.662 , respectively). These metals are likely present in the collected borehole water samples due to agricultural run-off or atmospheric deposition in the study area [36]. In addition, source of heavy metals in the water sample taken from the hotel (B1) could be as a result of linkages from sewage or toilets around the hotel to the groundwater.

The relationships among the metals were determined by HCA and they were grouped into clusters based on the similarities and dissimilarities between different metals. Dendrogram analysis produced 3 clusters in January and 2 clusters in April and June based on the spatial distribution of metals within these months (Fig. 3). Cluster 1 in January for all samples contained $\mathrm{Cr}, \mathrm{Zn}, \mathrm{Cu}, \mathrm{Pb}$ and 
Cd, cluster 2 include $\mathrm{Mn}$ and cluster 3 has Fe (Fig. 3a). Cluster 1 in the dendrogram generated for April is similar with the aforementioned cluster 1 , while cluster 2 consists of Fe and Mn (Fig. 3b). In June, cluster 1 has Fe, while 2 is formed by $\mathrm{Mn}, \mathrm{Cu}, \mathrm{Zn}, \mathrm{Cr}, \mathrm{Pb}$ and $\mathrm{Cd}$ (Fig. 3b). The results of cluster analysis supported the correlation results, which suggested that the selected metals are from anthropogenic and natural sources. Occurrence of $\mathrm{Mn}, \mathrm{Fe}, \mathrm{Cd}$ and $\mathrm{Zn}$ indicated agricultural and domestic sewage contamination. Run-off of fertilizers or fungicides from the farm, leachates into through the aquifer to the groundwater could also affect water quality [24, 48]. Multivariate analysis using PCA/FA is very useful as a monitoring tools to identify the multiple sources of contaminants and relationships with metals in the groundwater. The PCA and HCA agreed with each other and showed the significant contributions and sources of these metals in groundwater samples. Studies have shown that application of fertilizer during farming are one of the well-known sources of $\mathrm{Cd}$ and $\mathrm{Cu}$ contamination in groundwater [24, 48].

\section{Evaluation of human health risk due to heavy metals in groundwater samples}

Health risk assessment model by the US. EPA were used to evaluate the health risks that heavy metals could pose on human via direct ingestion and dermal absorption of groundwater in Muledane village. The level of exposure through $\mathrm{EX}_{\text {ing }}$ and $\mathrm{EX}_{\text {derm }}$ were estimated for the months of January, April and June. The results suggested that contaminants from the boreholes around Muledane via ingestion and dermal pathways were the major exposure routes to humans in this village. Health related risk associated with the exposure through ingestion depends on the weight, age and volume of groundwater consumed by an individual this was determined using the measured minimum and maximum concentration of $\mathrm{Cr}, \mathrm{Cd}, \mathrm{Zn}$, $\mathrm{Pb}, \mathrm{Mn}, \mathrm{Fe}$ and $\mathrm{Cu}$.

The hazard quotient (HQ) which is a numeric estimate of the systemic toxicity potential posed by a single element within a single route of exposure was calculated and both $\mathrm{HQ}_{\mathrm{in}}$ and $\mathrm{HQ}_{\text {derm }}$ in January, April and June for all the metals were less than one unity (Table 5) for adults and children. This indicates that little or no adverse health effect are likely to be caused by all these metals when the groundwater is consumed or via dermal adsorption by all ages. The $\mathrm{HQ}_{\text {in }}$ and $\mathrm{HQ}_{\text {derm }}$ decreased in the order of $\mathrm{Cd}>\mathrm{Cr}>\mathrm{Mn}>\mathrm{Zn}>\mathrm{Pb}>\mathrm{Cu}>\mathrm{Fe}$ and $\mathrm{Cr}>\mathrm{Mn}>\mathrm{Zn}>\mathrm{Pb}>\mathrm{Cd}>\mathrm{Cu}>\mathrm{Fe}>\mathrm{Zn}$, for both children and adults in January, respectively. $\mathrm{HQ}_{\mathrm{in}}$ and $\mathrm{HQ}_{\text {derm }}$ decreased in the order of $\mathrm{Mn}>\mathrm{Pb}>\mathrm{Cr}>\mathrm{Cu}$ $>\mathrm{Zn}>\mathrm{Cd}>\mathrm{Fe}$ and $\mathrm{Mn}>\mathrm{Cr}>\mathrm{Pb}>\mathrm{Cd}>\mathrm{Cu}>\mathrm{Fe}>\mathrm{Z}$ $\mathrm{n}$, respectively in April, while the order for June were $\mathrm{Pb}>\mathrm{Mn}>\mathrm{Cr}>\mathrm{Zn}>\mathrm{Cu}>\mathrm{Cd}>\mathrm{Fe}$ and $\mathrm{Cr}>\mathrm{Mn}>\mathrm{Pb}$ $>\mathrm{Cd}>\mathrm{Cu}>\mathrm{Fe}>\mathrm{Zn}$, respectively for both children and adults. The $\mathrm{HQ}_{\mathrm{Mn}}$ is the second abundant in January for $\mathrm{HQ}_{\text {derm }}$ for both pathways in June, while the highest was estimated throughout the pathways in April for all ages, respectively. The results are similar to the findings of Elumalai et al. [24], in which $\mathrm{HQ}_{\text {ing }}$ for $\mathrm{Mn}$ concentration in groundwater for children were higher than one unity. Likewise, $\mathrm{Cr}$ that is classified as a known human carcinogenic agent via inhalation is of public health concern. In this study, the highest hazard quotient for $\mathrm{Cr}$ through dermal adsorption were observed in January and June, while in April, it has the highest values for both adults and children (Table 5). It has been reported that $\mathrm{Cr}$ could originate from different sources either natural or anthropogenic with high environmental mobility $[49,50]$. However, it has been suggested that estimated HQ values for metals $>1$ for children should not be neglected [51, 52], because children are highly susceptible to pollutants [53].

Table 3 Factor loadings of selected heavy metals in the borehole water samples during the monitoring period

\begin{tabular}{|c|c|c|c|c|c|c|}
\hline \multirow[t]{2}{*}{ Selected metals } & \multicolumn{2}{|l|}{ January } & \multicolumn{2}{|l|}{ April } & \multicolumn{2}{|l|}{ June } \\
\hline & PC1 & $\mathrm{PC2}$ & PC1 & PC2 & PC1 & $\mathrm{PC2}$ \\
\hline $\mathrm{Cr}$ & 0.274 & 0.351 & -0.684 & -0.568 & -0.063 & 0.955 \\
\hline $\mathrm{Cu}$ & 0.864 & -0.466 & 0.718 & -0.092 & -0.510 & -0.009 \\
\hline $\mathrm{Fe}$ & 0.662 & -0.357 & 0.855 & -0.355 & 0.897 & 0.031 \\
\hline $\mathrm{Mn}$ & -0.596 & 0.079 & 0.889 & -0.238 & 0.902 & 0.097 \\
\hline $\mathrm{Pb}$ & -0.316 & 0.609 & -0.715 & -0.538 & 0.052 & 0.881 \\
\hline $\mathrm{Zn}$ & 0.546 & 0.680 & -0.135 & -0.815 & 0.866 & 0.127 \\
\hline $\mathrm{Cd}$ & 0.690 & 0.596 & -0.350 & 0.864 & 0.707 & -0.305 \\
\hline Eigenvalue & 2.490 & 1.662 & 3.157 & 2.215 & 2.821 & 1.579 \\
\hline Variability (\%) & 35.568 & 23.750 & 45.093 & 31.648 & 40.300 & 22.559 \\
\hline Cumulative \% & 35.568 & 59.318 & 45.093 & 76.741 & 40.300 & 62.859 \\
\hline
\end{tabular}


The main contributors for non-carcinogenic health risk in both pathways were $\mathrm{Mn}, \mathrm{Pb}, \mathrm{Cr}$ and $\mathrm{Cd}$.

The calculated cumulative hazard quotients (HI) across metal served as a conservative assessment tool to estimate high-end risk rather than low end-risk in order to protect the public (Table 5). This served as a screen value to determine whether there is major significant health risk that exposure of heavy metals in the groundwater may pose on the villagers and if there is any difference in total health risk during the study period. The estimated total HQ values were less than one (Table 5), therefore, exposure to these elements through mouth ingestion and dermal adsorption through the skin may likely not exert negative or cumulative adverse risk on the inhabitants of this village.

The average estimated minimum and maximum values for chronic daily intake (CDI) for the selected heavy metals in groundwater samples collected from the boreholes around Muledane via ingestion pathway for both adults and children are shown in Table 6. The maximum $\mathrm{CDI}$ values for the selected metals in January, April and June ranged between $5.85 \mathrm{E}-02-4.17 \mathrm{E}-05,3.82 \mathrm{E}-02-$ $6.29 \mathrm{E}-05$ and $4.56 \mathrm{E}-02-4.17 \mathrm{E}-05$ for adults, while children index was 2.23E-01-2.40E-04, 1.46E-01$2.40 \mathrm{E}-04$ and $1.74 \mathrm{E}-01-1.80 \mathrm{E}-04$, respectively. The CDI indices for heavy metals during the study period for both ages were found to be in the order of $\mathrm{Fe}>\mathrm{Mn}$ $>\mathrm{Zn}>\mathrm{Cr}>\mathrm{Cu}>\mathrm{Pb}>\mathrm{Cd}$ in January; $\mathrm{Mn}>\mathrm{Fe}>\mathrm{Cu}>$ $\mathrm{Zn}>\mathrm{Cr}>\mathrm{Pb}>\mathrm{Cd}$ in April and finally $\mathrm{Fe}>\mathrm{Mn}>\mathrm{Cu}$ $>\mathrm{Zn}>\mathrm{Cr}>\mathrm{Pb}>\mathrm{Cd}$ in June (Table 6). In the drinking water of Muledane groundwater, high CDI values of $\mathrm{Mn}, \mathrm{Fe}$ and $\mathrm{Cu}$ were estimated for both adults and children, also high estimated values for children ingesting $\mathrm{Zn}$ were observed throughout the study. Wu et al. [35] and Naveedullah et al. [34] suggested that high $\mathrm{Zn}, \mathrm{Mn}$ and Fe are from agricultural practices such as run-off from extensive farming area, use of fungicides and fertilizers affect water quality. In general, health risk assessment index using the overall non-carcinogenic risk assessment (HI), CDI and HQ via ingestion and dermal adsorption routes were less than one unity. This is an indication that groundwater poses less significant health threats to both adults and children via the pathways [33, 35], however measures should be made to avoid accumulation of heavy metals that could pose any health problems especially in children.

Table 4 Pearson correlation matrix among metals in the groundwater samples

\begin{tabular}{|c|c|c|c|c|c|c|c|}
\hline Variables & $\mathrm{Cr}$ & $\mathrm{Cu}$ & $\mathrm{Fe}$ & $\mathrm{Mn}$ & $\mathrm{Pb}$ & $Z n$ & $\mathrm{Cd}$ \\
\hline \multicolumn{8}{|l|}{ January } \\
\hline $\mathrm{Cr}$ & 1 & 0.069 & 0.371 & 0.070 & 0.256 & 0.199 & 0.169 \\
\hline $\mathrm{Cu}$ & 0.069 & 1 & 0.734 & -0.633 & -0.444 & 0.099 & 0.307 \\
\hline $\mathrm{Fe}$ & 0.371 & 0.734 & 1 & -0.041 & -0.231 & -0.064 & 0.272 \\
\hline $\mathrm{Mn}$ & 0.070 & -0.633 & -0.041 & 1 & 0.070 & -0.265 & -0.241 \\
\hline $\mathrm{Pb}$ & 0.256 & -0.444 & -0.231 & 0.070 & 1 & -0.066 & 0.107 \\
\hline $\mathrm{Zn}$ & 0.199 & 0.099 & -0.064 & -0.265 & -0.066 & 1 & 0.779 \\
\hline $\mathrm{Cd}$ & 0.169 & 0.307 & 0.272 & -0.241 & 0.107 & 0.779 & 1 \\
\hline \multicolumn{8}{|l|}{ April } \\
\hline $\mathrm{Cr}$ & 1 & -0.267 & -0.359 & -0.336 & 0.971 & 0.312 & -0.169 \\
\hline $\mathrm{Cu}$ & -0.267 & 1 & 0.576 & 0.710 & -0.245 & -0.124 & -0.142 \\
\hline $\mathrm{Fe}$ & -0.359 & 0.576 & 1 & 0.823 & -0.386 & 0.136 & -0.559 \\
\hline $\mathrm{Mn}$ & -0.336 & 0.710 & 0.823 & 1 & -0.397 & -0.118 & -0.500 \\
\hline $\mathrm{Pb}$ & 0.971 & -0.245 & -0.386 & -0.397 & 1 & 0.351 & -0.081 \\
\hline $\mathrm{Zn}$ & 0.312 & -0.124 & 0.136 & -0.118 & 0.351 & 1 & -0.712 \\
\hline $\mathrm{Cd}$ & -0.169 & -0.142 & -0.559 & -0.500 & -0.081 & -0.712 & 1 \\
\hline \multicolumn{8}{|l|}{ June } \\
\hline $\mathrm{Cr}$ & 1 & 0.168 & 0.019 & 0.070 & 0.717 & 0.125 & -0.386 \\
\hline $\mathrm{Cu}$ & 0.168 & 1 & -0.327 & -0.381 & -0.199 & -0.263 & -0.287 \\
\hline $\mathrm{Fe}$ & 0.019 & -0.327 & 1 & 0.995 & -0.063 & 0.662 & 0.398 \\
\hline $\mathrm{Mn}$ & 0.070 & -0.381 & 0.995 & 1 & 0.010 & 0.663 & 0.379 \\
\hline $\mathrm{Pb}$ & 0.717 & -0.199 & -0.063 & 0.010 & 1 & 0.139 & -0.026 \\
\hline $\mathrm{Zn}$ & 0.125 & -0.263 & 0.662 & 0.663 & 0.139 & 1 & 0.738 \\
\hline $\mathrm{Cd}$ & -0.386 & -0.287 & 0.398 & 0.379 & -0.026 & 0.738 & 1 \\
\hline
\end{tabular}



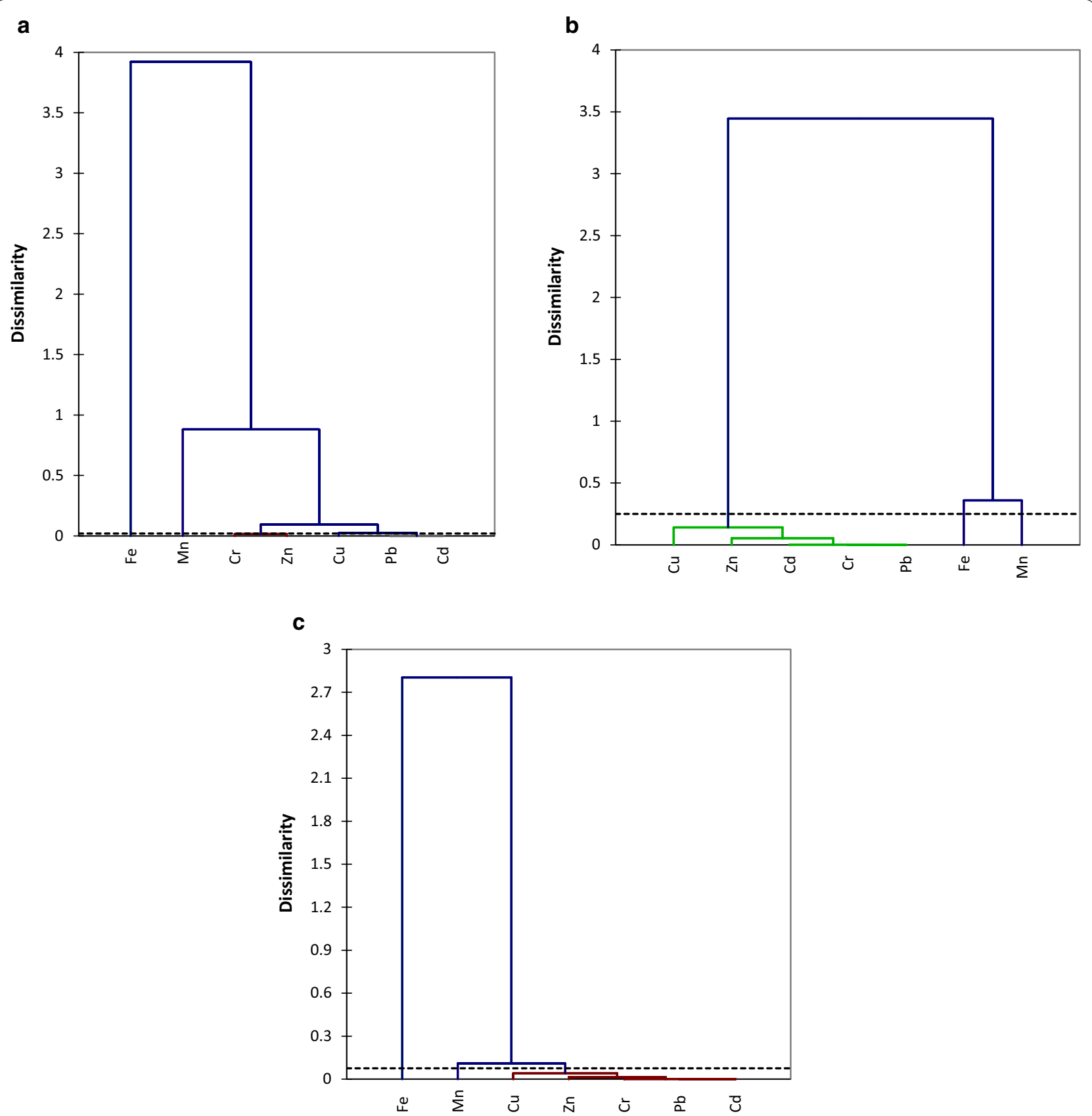

Fig. 3 Dendrogram showing the spatial clustering of selected heavy metals in water samples from Muledane boreholes during the monitoring periods based on the hierarchical cluster analysis using Ward's method

Carcinogenic risk $\left(\mathrm{CR}_{\text {ing }}\right)$ defined as the incremental probability that an individual will develop cancer during one's lifetime due to exposure under specific scenarios were calculated for the selected metals in this study [35]. Only carcinogenic risk of $\mathrm{Cr}, \mathrm{Pb}$ and $\mathrm{Cd}$ for Muledane groundwater were calculated for both adults and children, because the value of carcinogenic slope factor for $\mathrm{Cu}, \mathrm{Fe}, \mathrm{Mn}$ and $\mathrm{Zn}$ could not be found in the literature.
The maximum estimated $\mathrm{CR}_{\text {ing }}$ values are shown in Table 7. Throughout the study, the average levels of $\mathrm{CR}_{\text {ing }}$ for $\mathrm{Pb}$ ranged between $3.05 \mathrm{E}-05-9.29 \mathrm{E}-05$ for adults and $1.16 \mathrm{E}-04-3.55 \mathrm{E}-04$ for children. In general, under most regulatory program the carcinogenic risk values between $10^{-6}$ and $10^{-4}$ for an individual suggest potential risk, hence the results in this study suggested that the level of $\mathrm{Cr}$ and $\mathrm{Pb}$ in the groundwater could pose 


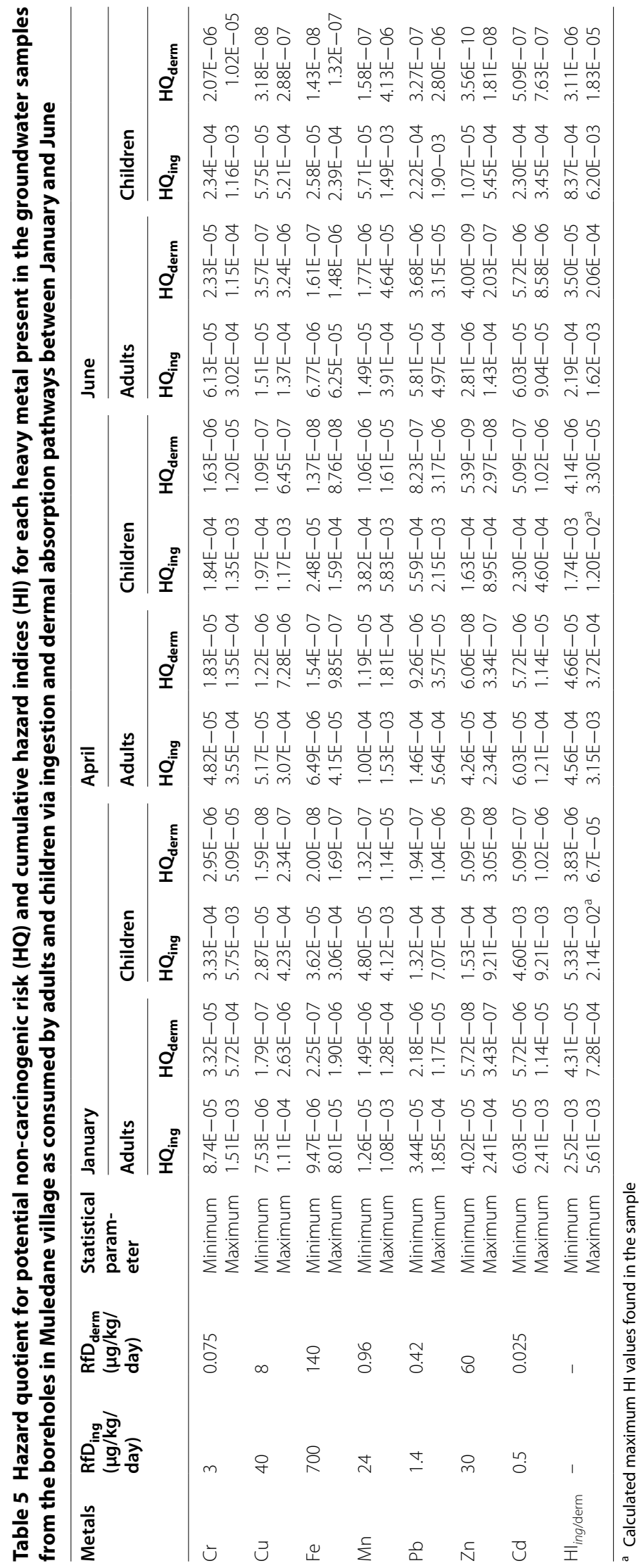


Table 6 Chronic risk assessment $\left(\mathrm{CDI}_{\text {ing }}\right)$ of heavy metals in groundwater samples taken around Muledane village through daily ingestion pathway during January, April and June for adults and children

\begin{tabular}{|c|c|c|c|c|c|c|}
\hline \multirow[t]{2}{*}{ Metals } & \multicolumn{2}{|l|}{ January } & \multicolumn{2}{|l|}{ April } & \multicolumn{2}{|l|}{ June } \\
\hline & Adults & Children & Adults & Children & Adults & Children \\
\hline $\mathrm{Cr}$ & $2.73 \mathrm{E}-04-4.71 \mathrm{E}-03$ & $1.04 \mathrm{E}-03-1.80 \mathrm{E}-02$ & $1.51 \mathrm{E}-04-1.11 \mathrm{E}-03$ & $5.76 \mathrm{E}-04-4.24 \mathrm{E}-03$ & 1.92E-04-9.46E-04 & 7.30E-04-3.61E-03 \\
\hline $\mathrm{Cu}$ & $3.144 \mathrm{E}-04-4.62 \mathrm{E} 03$ & 1.20E-03-1.76E-02 & $2.16 \mathrm{E}-03-1.28 \mathrm{E}-02$ & $8.23 \mathrm{E}-03-4.89 \mathrm{E}-02$ & $6.29 \mathrm{E}-04-5.69 \mathrm{E}-03$ & $2.40 \mathrm{E}-03-2.17 \mathrm{E}-02$ \\
\hline $\mathrm{Fe}$ & $6.91 E-03-5.85 E-02$ & $2.64 \mathrm{E}-02-2.23 \mathrm{E}-01$ & 4.74E-03-3.03E-02 & $1.81 \mathrm{E}-02-1.16 \mathrm{E}-01$ & $4.94 \mathrm{E}-03-4.56 \mathrm{E}-02$ & $1.89 \mathrm{E}-02-1.74 \mathrm{E}-01$ \\
\hline $\mathrm{Mn}$ & $3.14 \mathrm{E}-04-2.70 \mathrm{E}-02$ & $1.20 \mathrm{E}-03-1.03 \mathrm{E}-01$ & $2.50 \mathrm{E}-03-3.82 \mathrm{E}-02$ & $9.56 \mathrm{E}-03-1.46 \mathrm{E}-01$ & 3.74E-04-9.80E-03 & $1.43 \mathrm{E}-03-3.74 \mathrm{E}-02$ \\
\hline $\mathrm{Pb}$ & $5.03 E-05-2.70 E-04$ & $1.92 \mathrm{E}-04-1.03 \mathrm{E}-03$ & $2.14 \mathrm{E}-04-8.23 \mathrm{E}-04$ & $8.16 \mathrm{E}-04-3.14 \mathrm{E}-03$ & $8.49 \mathrm{E}-05-7.26 \mathrm{E}-04$ & $3.24 \mathrm{E}-04-2.77 \mathrm{E}-03$ \\
\hline $\mathrm{Zn}$ & $1.26 \mathrm{E}-03-7.54 \mathrm{E}-03$ & 4.80E-03-2.88E-02 & 1.33E-03-7.34E-03 & $5.09 \mathrm{E}-03-2.80 \mathrm{E}-02$ & $8.80 \mathrm{E}-05-4.46 \mathrm{E}-03$ & $3.36 \mathrm{E}-04-1.70 \mathrm{E}-02$ \\
\hline $\mathrm{Cd}$ & $3.14 \mathrm{E}-05-6.29 \mathrm{E}-05$ & 1.20E-04-2.40E-04 & $3.14 \mathrm{E}-05-6.29 \mathrm{E}-05$ & $1.20 \mathrm{E}-04-2.40 \mathrm{E}-04$ & $3.14 \mathrm{E}-05-4.17 \mathrm{E}-05$ & $1.20 \mathrm{E}-04-1.80 \mathrm{E}-$ \\
\hline
\end{tabular}

Table 7 Carcinogenic risk assessment $\left(\mathbf{C R}_{\text {ing }}\right)$ of $\mathbf{C r}, \mathbf{P b}$ and $\mathbf{C d}$ at different times of groundwater samples collected around Muledane village through ingestion pathway for adults and children between January, April and June

\begin{tabular}{|c|c|c|c|c|c|c|}
\hline \multirow[t]{2}{*}{ Metals } & \multicolumn{2}{|l|}{ January } & \multicolumn{2}{|l|}{ April } & \multicolumn{2}{|l|}{ June } \\
\hline & Adults & Children & Adults & Children & Adults & Children \\
\hline $\mathrm{Cr}$ & $5.24 \mathrm{E}-07-9.04 \mathrm{E}-06$ & $2.00 E-06-3.45 E-05$ & $2.89 E-07-2.13 E-06$ & $1.10 \mathrm{E}-06-8.12 \mathrm{E}-06$ & $3.68 \mathrm{E}-07-1.81 \mathrm{E}-06$ & $1.40 \mathrm{E}-06-6.93 \mathrm{E}-06$ \\
\hline $\mathrm{Pb}$ & $5.67 E-06-3.05 E-05$ & $2.17 \mathrm{E}-05-1.16 \mathrm{E}-04$ & $2.41 E-05-9.29 E-05$ & $9.21 E-05-3.55 E-04$ & $9.57 E-06-8.19 E-05$ & $3.66 \mathrm{E}-05-3.13 \mathrm{E}-04$ \\
\hline $\mathrm{Cd}$ & 4.94E-09-9.88E-09 & $1.89 \mathrm{E}-08-3.77 \mathrm{E}-08$ & 4.94E-09-9.88E-09 & $1.89 \mathrm{E}-08-3.77 \mathrm{E}-08$ & 4.94E-09-7.41E-09 & $1.89 \mathrm{E}-08-2.83 \mathrm{E}-08$ \\
\hline
\end{tabular}

carcinogenic risk to both adults and children. Therefore, proper control measures to protect the health of humans around the study area should be put in place in order to ensure safety of consumers. Also, concerted efforts are required for sustainability of the groundwater by removing these metals.

\section{Conclusions}

Only $12.5 \%$ boreholes have ideal water quality in terms of $\mathrm{NO}_{3}{ }^{-}$and $\mathrm{Mn}$ concentration with $25 \%$ found to be in the marginal water quality class, while $75 \%$ percent fell in the unacceptable water quality class. In terms of chemical properties, it is unsafe for resident around Muledane within the investigated area to use the boreholes water for domestic purposes without treatment. This study reveals that $87.5 \%$ borehole water have high concentration of $\mathrm{NO}_{3}$; Fe and $\mathrm{Mn}$ among the selected anions and heavy metals. The measured concentration of $\mathrm{Cr}$, Fe and $\mathrm{Mn}$ for some of the investigated boreholes were observed to be higher than the recommended standard limits by WHO and DWAF. The HQ and the overall non-carcinogenic health hazard indices (HI) through the ingestion and dermal adsorption of the groundwater were less than one. However, the results showed the potential risk of some of the selected metals on human, especially children. The main contributors to non-carcinogenic risk were $\mathrm{Mn}$, $\mathrm{Zn}, \mathrm{Pb}, \mathrm{Cr}$ and $\mathrm{Cd}$ for both pathways. The results of this study further revealed that ingestion of the investigated boreholes poses carcinogenic risk $\left(\mathrm{CR}_{\text {ing }}\right)$ regarding the estimated $\mathrm{Mn}, \mathrm{Fe}$ and $\mathrm{Cu}$ for adults and children. In addition to the aforementioned metals, estimated $\mathrm{CR}_{\text {ing }}$ for $\mathrm{Zn}$ among children were high throughout the study. It is therefore recommended that water quality studies should be given a priority by adding it into the integrated development plans (IDPs) and be conducted on a regular basis to assess risks of contamination. Health and hygiene education is highly needed for people in rural areas because of lack of proper sanitation and proper water handling practices. In addition, further studies are recommended to investigate the point sources of contamination and possible causes of high concentration of nitrate level in the boreholes around Muledane village.

\section{Authors' contributions}

JNE, NM and JOO designed, collect the data and laboratory experimentation, AME and JNE handled data analyses, Interpretation of results and preparation of the manuscript. All authors read and approved the final manuscript.

\section{Acknowledgements}

The authors are grateful to Directorate of Research and Innovation, University of Venda, South Africa for the financial assistance in covering the costs of publishing this article in an open access journal.

\section{Competing interests}

The authors declare that they have no competing interests.

Availability of data and materials

Not applicable.

Consent for publication

Not applicable. 
Ethics approval and consent to participate

Not applicable.

\section{Publisher's Note}

Springer Nature remains neutral with regard to jurisdictional claims in published maps and institutional affiliations.

Received: 8 November 2017 Accepted: 20 December 2017 Published online: 12 January 2018

\section{References}

1. Edokpayi JN, Odiyo JO, Msagati TA, Potgieter N (2015) Temporal variations in physico-chemical and microbiological characteristics of Mvudi River, South Africa. Int J Environ Res Public Health 12(4):4128-4140

2. Chakraborti D, Rahman MM, Ahamed S, Dutta RN, Pati S, Mukherjee SC (2016) Arsenic contamination of groundwater and its induced health effects in Shahpur block, Bhojpur district, Bihar state, India: risk evaluation. Environ Sci Pollut Res 23(10):9492-9504

3. Indelicato S, Orecchio S, Avellone G, Bellomo S, Ceraulo L, Di Leonardo R et al (2017) Effect of solid waste landfill organic pollutants on groundwater in three areas of Sicily (Italy) characterized by different vulnerability. Environ Sci Pollut Res 20:1-14

4. Majolagbe AO, Adeyi AA, Osibanjo O (2016) Vulnerability assessment of groundwater pollution in the vicinity of an active dumpsite (Olusosun), Lagos, Nigeria. Chem Int 2:232-241

5. Chen M, Qin X, Zeng G, Li J (2016) Impacts of human activity modes and climate on heavy metal "spread" in groundwater are biased. Chemosphere 152:439-445

6. Gu X, Xiao Y, Yin S, Pan X, Niu Y, Shao J et al (2017) Natural and anthropogenic factors affecting the shallow groundwater quality in a typical irrigation area with reclaimed water, North China Plain. Environ Monit Assess 189(10):514

7. Lee E, Ha K, Ngoc NTM, Surinkum A, Jayakumar R, Kim Y et al (2017) Groundwater status and associated issues in the Mekong-Lancang River Basin: international collaborations to achieve sustainable groundwater resources. J Groundw Sci Eng 5(1):1-13

8. Aslam RA, Shrestha S, Pandey VP (2018) Groundwater vulnerability to climate change: a review of the assessment methodology. Sci Total Environ 612:853-875

9. Misra AK (2014) Climate change and challenges of water and food security. Int J Sustain Built Environ 3(1):153-165

10. Hynds PD, Thomas MK, Pintar KDM (2014) Contamination of groundwater systems in the US and Canada by enteric pathogens, 1990-2013: a review and pooled-analysis. PLoS ONE 9(5):e93301

11. Lindgren JF, Salo K, Brynolf S, Andersson K, Svensson E, Zetterdahl M et al (2016) The natural environment and human impacts. Shipping and the environment. Springer, Berlin, pp 29-74

12. Adams S, Cobbing J, Dennis I, Riemann K (2012) Groundwater: our source of security in an uncertain future. Water SA 38(3):357-358

13. Baguma A, Bizoza A, Carter R, Cavill S, Foster S, Foster T, et al (2017) Groundwater and poverty in sub Saharan Africa a short investigation highlighting outstanding knowledge gaps. Report, pp 1-105 (Edited by Prof. Richard Carter)

14. DWAF (2000) Quality of domestic water supply. Volume 2: sampling guide: $3,4,17$

15. Pietersen K, Beekman HE, Holland M (2011) South African Groundwater Governance Case Study. Final report prepared for the World Bank economic and sector analysis "Improving groundwater governance: The political economy of groundwater policy and institutional reforms. In partnership with the South African Dept. of Water Affairs and the WRC

16. Afangideh A, Njar G, Ewa E, Eli H, Iwara A (2011) Assessment of water quality status of borehole in Calabar South local government area, Cross River State. Int J Biosci (IJB) 1(5):71-76

17. Ramakrishnaiah C, Sadashivaiah C, Ranganna G (2009) Assessment of water quality index for the groundwater in Tumkur Taluk, Karnataka State, India. J Chem 6(2):523-530

18. Makwe E (2012) Assessing water quality for human consumption within the Vicinity of Karu Abattoir. Abuja FCT, Nigeria an unpublished MSc
Dissertation submitted to the Department of Geography and Environmental Management, University of Abuja, Nigeria

19. Bessong PO, Odiyo JO, Musekene JN, Tessema A (2009) Spatial distribution of diarrhoea and microbial quality of domestic water during an outbreak of diarrhoea in the Tshikuwi community in Venda, South Africa. J Health Popul Nutr 27(5):652

20. Odiyo JO, Makungo R (2012) Fluoride concentrations in groundwater and impact on human health in Siloam Village, Limpopo Province, South Africa. Water SA 38(5):731-736

21. Munyangane $P$, Mouri H, Kramers J (2017) Assessment of some potential harmful trace elements (PHTEs) in the borehole water of Greater Giyani, Limpopo Province, South Africa: possible implications for human health. Environ Geochem Health 39(5):1201-1219

22. Fatta D, Papadopoulos A, Loizidou M (1999) A study on the landfill leachate and its impact on the groundwater quality of the greater area. Environ Geochem Health 21(2):175-190

23. Esterhuizen L, Fossey A, Lues J (2012) Dairy farm borehole water quality in the greater Mangaung region of the Free State Province, South Africa. Water SA 38(5):803-806

24. Elumalai $\bigvee$, Brindha $K$, Lakshmanan E (2017) Human exposure risk assessment due to heavy metals in groundwater by pollution index and multivariate statistical methods: a case study from South Africa. Water 9(4):234 https://doi.org/10.3390/w9040234

25. Thulamela Municipality (2013) A review of Thulamela Municipality Integrated Development Plan. 2010/11-2012/13, Limpopo, South Africa

26. Mailula M (2010) Assessment of microbial safety of surface water sources of Luvuvhu river catchment. Honours thesis, unpublished University of Venda

27. Keyser N (1997) Geological map of the Republic of South Africa and the kingdoms of Lesotho and Swaziland. Council for Geoscience, South Africa

28. Musekiwa C, Majola K (2013) Groundwater vulnerability map for South Africa. S Afr J Geomat 2(2):152-162

29. Fifield FW, Haines PJ (2000) Environmental analytical chemistry. In: Buckly D, Hoot EM, Christie GL, laird CK, Manly R, Ward NI, Welchc CJ (eds). WileyBlackwell, London

30. Sharma B, Tyagi S (2013) Simplification of metal ion analysis in fresh water samples by atomic absorption spectroscopy for laboratory students. J ab Chem Educ 1(3):54-58

31. USEPA (1989) Risk assessment guidance for superfund, vol 1, human health evaluation manual (part A), Report EPA/540/1-89/002, United States Environmental Protection Agency, Washington, DC

32. Li SY, Zhang QF (2010) Spatial characterization of dissolved trace elements and heavy metals in the upper Han River (China) using multivariate statistical techniques. J Hazard Mater 176(1-3):579

33. Asare-Donkor NK, Boadu TA, Adimado AA (2016) Evaluation of groundwater and surface water quality and human risk assessment for trace metals in human settlements around the Bosomtwe Crater Lake in Ghana. SpringerPlus 5(1):1812 (PubMed PMID: PMC5069212)

34. Naveedullah MZH, Yu C, Shen H, Duan D, Shen C et al (2014) Concentration and human health risk assessment of selected heavy metals in surface water of the siling reservoir watershed in Zhejiang Province, China. Pol J Environ Stud 23(3):801-811

35. Wu B, Zhao DY, Jia HY, Zhang Y, Zhang XX, Cheng SP (2009) Preliminary risk assessment of trace metal pollution in surface water from Yangtze River in Nanjing Section, China. Bull Environ Contam Toxicol 82(4):405-409

36. Iqbal J, Shah MH (2013) Health risk assessment of metals in surface water from freshwater source lakes Pakistan. Hum Ecol Risk Assess Inter J 19(6):1530-1543

37. USEPA (2009) Drinking water standards and health advisories, EPA 822-R09-011. Office of water, Washington, DC, USA

38. DWAF DoWAaF (1996) South African water quality guidelines, vol 1 , 2nd edn. Domestic Water Use Department of Water Affairs and Forestry Pretoria, Pretoria

39. WHO (2006) Guidelines for drinking-water quality, addendum to volume 1: recommendations, 3rd edn. World Health Organization, Geneva

40. Shan MH, lqbal J, Shaheen N, Khan N, Choudhary MA, Akhter G (2012) Assessment of background levels of trace metals in water and soil from a remote region of Himalaya. Environ Monit Assess 184(3):1243-1252

41. DWAF DoWAaF. Quality of domestic water supplies assessment guide. Water Research Commission. 1998;1:Report No:TT.101/98 
42. Lenntech (2013) Water treatment solution. www.lenntech.com/periodic/ water/chromium/chromiumand-water.htm\#ixzz2WINpbky5. Accessed 16 June 2013

43. Kart A, Koc E, Dalginli KY, Gulmez C, Sertcelik M, Atakisi O (2016) The therapeutic role of glutathione in oxidative stress and oxidative DNA damage caused by hexavalent chromium. Biol Trace Elem Res 174(2):387-391

44. Novotnik B, Ščančar J, Milačič R, Filipič M, Žegura B (2016) Cytotoxic and genotoxic potential of $\mathrm{Cr}(\mathrm{VI}), \mathrm{Cr}(\mathrm{III})$-nitrate and $\mathrm{Cr}(\mathrm{III})$-EDTA complex in human hepatoma (HepG2) cells. Chemosphere 154:124-131

45. WHO (1993) Guidelines for drinking water quality, volume 1: recommendations, 2nd edn. World Health Organization, Geneva

46. WHO (1996) Guidelines for drinking water, health criteria and other supporting information. Geneva; 1996, pp 940-949, Addendum to vol 2 1998. pp 281-283

47. Jaishankar M, Tseten T, Anbalagan N, Mathew BB, Beeregowda KN (2014) Toxicity, mechanism and health effects of some heavy metals. Interdiscip Toxicol 7(2):60-72

48. Wu J, Sun Z (2016) Evaluation of shallow groundwater contamination and associated human health risk in an alluvial plain impacted by agricultural and industrial activities, mid-west China. Expo Health 8(3):311-329
49. Zhitkovich A (2011) Chromium in drinking water: sources, metabolism, and cancer risks. Chem Res Toxicol 24(10):1617

50. Kotaś J, Stasicka Z (2000) Chromium occurrence in the environment and methods of its speciation. Environ Pollut 107(3):263-283

51. Sudsandee S, Tantrakarnapa K, Tharnpoophasiam P, Limpanont Y, Mingkhwan R, Worakhunpiset S (2017) Evaluating health risks posed by heavy metals to humans consuming blood cockles (Anadara granosa) from the Upper Gulf of Thailand. Environ Sci Pollut Res 24(17):14605-14615

52. Giandomenico S, Cardellicchio N, Spada L, Annicchiarico C, Di Leo A (2016) Metals and PCB levels in some edible marine organisms from the Ionian Sea: dietary intake evaluation and risk for consumers. Environ Sci Pollut Res 23(13):12596-12612

53. Olujimi OO, Oputu O, Fatoki O, Opatoyinbo OE, Aroyewun OA, Baruani $J$ (2015) Heavy metals speciation and human health risk assessment at an illegal gold mining site in Igun, Osun State, Nigeria. J Health Pollut 5(8):19-32

\section{Submit your manuscript to a SpringerOpen ${ }^{\circ}$ journal and benefit from:}

- Convenient online submission

- Rigorous peer review

- Open access: articles freely available online

- High visibility within the field

- Retaining the copyright to your article

Submit your next manuscript at springeropen.com 